It is the policy of the Colonial Office to develop fish resources everywhere, and there is a vast field of work, in exploring and in improving, by experiment and precept, the natural fisheries, both fresh water and marine. But the product of the natural fisheries can be powerfully supplemented by the product of fish-ponds, especially where difficulties of transport and preservation stand in the way of meeting the requirements of the populations by fish from natural fisheries. There are big areas of marshy land, particularly in Africa and in the West Indies, which could be developed for fish farming, and fish farming could also be introduced wherever there is well-watered land undeveloped, or even in developed land as part of a mixed culture. Moreover, along the coasts there are many areas where marine fish-ponds could be laid out. The aim should be to make each community self-supporting for fish, or, still better, with a surplus to pass into the common supply.

The Colonial Office therefore plans to set up a research institute, on the scale of a first-class agricultural station, to study the fundamental processes underlying the high yields of fish-ponds, to study the genetics of fish and the physiology of breeding, and to get statistically controlled data of yields under a great variety of treatments. Here, also, fish culturists would be trained under experts.

The results of these fundamental researches would be applied, suitably modified, in each Colonial territory, and with communities of fish, preferably native fishes, best adapted to each.

${ }^{1}$ Bertram, C. K. Ricardo, Nature, 152, 415 (1943).

${ }^{2}$ Wimpenny, R. S., Report on Fisheries, Egypt (1928).

${ }^{3}$ Swynnerton, G. H., unpublished report on Lake Rukwa.

- Fishery Resources of the United States. Document 51, 79th Congress, 1st Session (Washington, 1945).

'Bertram, G. C. L., Empire J. Exp. Agric., 14, No. 56 (Oct. 1946).

${ }^{6}$ Lin, S. Y., J. Hong Kong Fisheries Res. Station, 1, No. 2 (1940).

"Birtwistle, W., Malayan Agric. J. (Aug. 1931).

${ }^{8}$ Hoffmann, W. E., Lingnan Univ. Sci. Bull., No. 5 (1934).

- Furnivall, W., "Fisheries in Netherlands Indies" (Burma Book Club, 1934).

${ }^{17}$ Chindambaram and Unny, Nature, 157, 375 (1946).

${ }^{11}$ Chen, T. P., Lingnan Univ. Sci. J., 13 (2), 275 (1934).

${ }^{12}$ Irvine, "Fishes of the Gold Coast"" (1948).

is Sunier, A. L. J., Treubia, 2, 157 (Sept. 1922).

14 Adams et al., Philippine J. Sci., 47, No. 1 (Jan. 1932).

${ }^{15}$ Frey, D. G., J. Mar. Res., 6, No. 3, 247 (1948).

${ }^{16}$ Pielou, D. P., Ann. Rept. Game and Tsetse Control Dept., N. Rhodesia (Lusaka, 1946).

${ }^{17}$ Worthington, E. B., Nature, 151, 353 (1943).

18 Overbeek, J. G., and Stoker, W. J., "Malaria in the Netherlands Indies and its Control" (Batavia:' Kolff and Co., 1937).

\section{MAX PLANCK MEMORIAL CEREMONY AT GÖTTINGEN}

A PRIL 23 of this year was the ninetieth anniversary of Max Planck's birth, and it had been the hope of his colleagues and admirers that the day might be the occasion of a simple festivity at which they could express their admiration and affection in the presence of the man in person. His death last October having prevented the realization of this wish, the Max-Planck-Gesellschaft zur Förderung der Wissenschaften (see later), the University of Göttingen, the Akademie der Wissenschaften of Göttingen and the Deutsche Physikalische Gesellschaft decided to celebrate the day by ceremonies devoted to the memory of Max Planck. Accordingly, on a bright spring day in the beautiful town of Göttingen, which fortunately is untouched by the hand of war, the character and achievements of the great man were fittingly celebrated by tributes in which appreciation of his scientific work and veneration for his personal qualities were equally balanced.

The first ceremony took place at 9 o'clock in the morning at his grave, marked by a simple stone, when wreaths were solemnly deposited by some of the foremost men of science in Germany, representing German universities, scientific societies and other bodies, and by representatives of certain scientific institutions of other lands. The British representatives were Sir Charles Darwin, representing the Royal Society; Prof. E. N. da C. Andrade, supported by Sir Robert Watson-Watt, representing the University of London; and Dr. B. K. Blount, representing the Research Branch of the Central Control Commission at Göttingen. Dr. Nordstrom represented the National Academy of Sciences of the United States and Prof. Otto Hahn laid a wreath on behalf of the Royal Swedish Academy. Many of the representatives spoke brief words of admiration of the great scientist. The occasion was deeply impressive. After a short interval the representatives proceeded to the Aula (Great Hall) of the University, where the main ceremony took place.

This was divided into two parts. The first consisted of brief addresses, delivered respectively by Prof. Otto Hahn, president of the Max-Planck-Gesellschaft zur Förderung der Wissenschaften; Prof. Hans Stille, vice-president of the Deutsche Akademie der Wissenschaften of Berlin, with which Planck was for so long prominently associated; Sir Charles Darwin, representing the Royal Society, of which Max Planck was a foreign member; and Prof. Hermann Dersch, representing the University of Berlin. A tribute from the Washington Academy of Sciences, written by Albert Einstein, was read by Prof. Hahn. The second part comprised three speeches in memory of Max Planck. Prof. Max von Laue spoke of the history, particularly the early history, of Planck's scientific work, laying stress on his handling of thermodynamic problems; Prof. Werner Heisenberg spoke particularly of the later developments of the quantum theory and of Planck's interest in recent work; Prof. Richard Becker dealt rather with the philosophical implications of Planck's work and with his human qualities. He introduced records of Max Planck's voice with striking effect. Throughout the ceremony, at which a large audience attended, the deep sincerity and controlled emotion of the speakers were evident, and the atmosphere was sustained by a simple and admirably chosen programme of music carried out by Karl Klinger, violinist, and Raimar Dahlgrün at the piano. Bach introduced the meeting, Brahms came between the two parts, and the last movement of Beethoven's Kreutzer sonata concluded the ceremony.

In the evening of the day of the ceremony an informal party ("Zwangloses Beisammensein") was given in a hall of the extensive premises of the Aerodynamisches Versuchsanstalt*, formerly devoted to aeronautical research for the German Government and now in the hands of the Research Branch of the Central Control Commission under Dr. B. K. Blount, to whose co-operation the party was due and to whose friendly efficiency the British visitors are much indebted. At this party various prominent German figures were present, including Otto Hahn, Lise Meitner, Max von Laue, Wermer Heisenberg, Ludwig Prandtl, R. W. Pohl, R. Becker, Erwin Meyer, E. Gruneisen, W. Meissner, J. Mattauch,

\footnotetext{
* Still known as 'AVA', although the first 'A' now indicates
} 
W. Koesters and others of world-wide repute, as well as the British and American representatives. It is pleasant to be able to record that the proceedings were without constraint and of the friendliest, so that it might have been a gathering of scientific friends at a German university before the First World War.

Many of those present for the ceremony stayed at Gottingen for a further day or two, and the occasion was one of much discussion of the newly founded Max-Planck-Gesellschaft, under which title the old Kaiser-Wilhelm-Gesellschaft has been reconstituted. This comprises thirty-four research institutes in the British and American Zones, of which six are at Göttingen. The president is Otto Hahn, the discoverer of uranium fission, and other Göttingen notabilities prominently associated with the Society are von Laue, Heisenberg and Windaus. The head of the management (Geschäftsführender Vorstand) is Dr. Ernst Telschow, who was a prominent figure at the discussions that took place. The Max Planck Institute for Physics under Werner Heisenberg is accommodated in a fine building of the AVA, and is largely concerned with cosmic rays, both from the theoretical and experimental points of view, with the particular aim of elucidating the reciprocal transformations of waves and particles. Superconductivity and astrophysics will also be prominent subjects of study. Theoretical work is in full swing, but so far it has not proved possible to erect the refrigerating apparatus necessary for experimental work on superconductivity. Much apparatus for cosmic ray research is already working.

Active work on the more theoretical aspects of aerodynamics and hydrodynamics is proceeding in the Max-Planck-Institut für Strömungsforschung under Walter Tollmien, who has succeeded Prandtl, still a prominent figure, though retired on account of age. In the same Institute much work is being carried out on friction. There are also Institutes for Brain Physiology, Medicine, Scientific Instruments and Physical Chemistry.

There are many difficulties in building up scientific work at Göttingen, but how they compare with those in Britain would be a matter for detailed study, possibly not without controversy. However, what is incontrovertible is that the spirit is excellent and that there is every hope that Göttingen will soon be once more an active source of scientific results of the highest importance. Much credit in this connexion is due to Dr. B. K. Blount, of the Control Commission, who has carried out a difficult task with equal tact and efficiency.

$$
\text { E. N. DA C. ANDrade }
$$

\section{LYON PLAYFAIR AND TECHNICAL EDUCATION IN BRITAIN}

\section{By W. H. G. ARMYTAGE University of Sheffield}

$\mathrm{T}$ HIS year marks the fiftieth anniversary of the death on May 29 of Lyon Playfair, chemist and statesman. In both roles he made a name that lives today, for as a chemist he played a large part in the discovery of the nitroprussides and (with Bunsen) made a valuable report on the gases evolved in iron furnaces; while as a statesman he urged, by every means in his power, the adoption of the new scientific knowledge and techniques. In both spheres he fulfilled the role of one of the chief architects of the system of technical education in Great Britain as it exists to-day.

The whole logic of Playfair's career lay in this. He was trained as a medical man; but his subsequent studies under, and friendship with, Liebig made him alive to the necessity of applying organic chemistry to other fields, as Liebig had applied it to agriculture. By the time he was twenty-four he had established such a reputation for himself that, when he wished to take up a professorship in Toronto, the Prime Minister personally requested him to stay in England. For his practical bent had been appreciated, and soon afterwards he was a professor at the School of Mines in Jermyn Street, exploring the possibilities of coal for steam navigation, and the causes of potato disease in Ireland. In view of all this activity, it was not surprising that he was elected to fellowship of the Royal Society when he was thirty.

The main event of Playfair's life was the Great Exhibition of 1851. The idea was Prince Albert's. Its projection was in the hands of a Royal Commission, and at times the Royal Commission clashed with Prince Albert's executive committee. Playfair was appointed as a liaison officer between the two bodies, and his grasp of the situation was responsible for the organisation of the juries being delegated to him. This work made his name. He was made a C.B. and given a place in the household of the Prince Consort. Henceforth, as the later exhibitions of 1862 and 1875 show, he was to be closely identified with this kind of work.

The Prince Consort was anxious to devote the profits of the Great Exhibition $(£ 186,436)$ to the practical application of science and art to productive industry. This scheme was vigorously supported by Playfair; so vigorously, in fact, that his vehemence on the subject caused him to be suspected of secular. ism. Eventually, when the report of the commissioners was published, it was decided to supplement the profits by a parliamentary grant of $£ 150,000$, and to purchase the three estates of Gore House (21 acres), Villiers (48 acres) and Harrington (17 acres). On this land, from now on called South Kensington, the Prince Consort intended to concentrate all the existing institutions already in existence. So ambitious a project, however, was not immediately practicable, and a start was made with the foundation of the Royal College of Science.

The real result of the Great Exhibition from our point of view was the establishment of a government department to encourage technical education, and it was, significantly enough, originally constituted under the Board of Trade as a dual department. Playfair was appointed as first secretary of the Science Department in 1853, and later, when the Art Department merged with the Science Depart. ment and came under the Committee of the Privy Council, he was made responsible for the united body. He now held a position vis-d-vis technical instruction as important as James Kay-Shuttleworth had held in the world of elementary education. But unfor. tunately for technical education, the Crimean War proved a serious handicap to his efforts. For not only were extensive grants to the new department impossible, but also Playfair's time was monopolized by the Government in experiment. The importance of his position was not lost on him, and he wrote a telling pamphlet called "Industrial Education on the Continent", demanding an official inquiry on the 